\title{
Gender, College Major Selections, Classifications Within Majors, And Its Relationship With Locus Of Control: An Empirical Evidence For Counseling Educators
}

\author{
Tunji Jemi-Alade, Priaire View A\&M University
}

\begin{abstract}
To help counselors develop strategies to enhance students' social, personal, and psychological well-being, this research provides an understanding of how students perceive their environment. Specifically examining graduate and undergraduate students, the researcher was concerned with ascertaining the effect of the college-major variable (Business Administration versus Health Care Administration) and classification (graduate versus undergraduate) of the internal versus external Locus of Control orientations. Employed in this investigation was a parametric procedure, which was the t-Test of independent samples. One hundred twenty-five (125) graduate and undergraduate students were selected to participate in this empirical study. The Social Reaction Inventory Questionnaire was used to collect the data regarding the internal versus external orientations of the college students. The investigative instrument had a split-half reliability coefficient of .82 for the test as a whole and was deemed to have excellent construct validity. The study concluded that Business and Health Care Administration students have similar overall Locus of Control orientation scores, graduate students have similar overall Locus of Control orientation scores, and counselors and other concerned individuals in the helping profession should be cognizant of the characteristics and traits of internally and externally oriented students.
\end{abstract}

\section{INTRODUCTION}

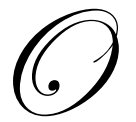

ne of the primary reasons often cited for the economic and social advances made by any society is its skill to manage large, complex enterprises. With regard to the latter notion, no nation has ever matched the United States in its use of human and natural resources (Flynn, 1992), yet we Americans are living in an era marked by tension and dissatisfaction with the status quo. This disenchantment is a problem since maintaining status quo is one of every nation's greatest strengths (Oregon Plan, 1990). Furthermore, the nation's ability to cope successfully with a myriad of stubborn problems is now being assailed and challenged by widespread, serious domestic ills (Bennerand \& Wrubel, 1989). To most Americans, though, national problems are not new. People have survived both internal and external strife; however, the nature and scope of many of the present challenges has not often been paralleled in the country's history (Dentzer, 1990). Therefore, the American public is looking for wise, resourceful, and pragmatic leadership. It is searching for cooperation (not just agreement) for solutions (not just answers), and in the health field, for physical and economic security (Aaron, 1991).

Most concepts concerning the propensity to view the self as being in control have included an internal Locus of Control, while other psychological constructs have denoted an external Locus of Control (Rotter, 1996). This control orientation is widely viewed as a core feature of personality consisting of a range of ramifications for 
life's satisfaction and well-being (Mortimer \& Lorence, 1981; Mortimer, Finch \& Kumba, 1973; Heath, 1976; Pearline \& Schooler, 1978). However, there seems to be considerable consensus that control orientation is not a fixed trait, but rather a response to successes and failures throughout life (Bandura, 1977; Deci \& Rya.

From the outside, a well-dressed, jacketed executive director behind the counter of a plush office symbolically represents the entire health administration profession. The executive director, or health administrator, is expected to decipher orders from the board of directors and physicians; to translate these into planning, directing, coordination, organizing, and budget operations; to answer an occasional query from the physician's patient; to settle labor disputes and nurse grievances; and to know where the medicine is shelved (Sloan, 1982). The outside client would not be likely to know whether the health administrator is a product of a six-month vocational program or has had advanced collegiate training. Health administration is, in short, the least understood of all professions in that its most visible practitioners perform stereotypical roles which, to a certain degree, do not appear to carry "professional" responsibilities (Glanty, 1990).

Most major management experts and professionals view the health care administrator's responsibilities as being divided into three broad areas: service-related, staff-related, and finance-related. The required skills include decision making, negotiating, interpersonal relations, and communication (Sorkin, 1991). However, many skills, especially those that are more vigorous and technical, such as utilization of human resources, can only be acquired under the direction of skilled educators. Quantitative and epidemiological methods, of basic importance in all aspects of planning and evaluation, quite clearly fall into this category (Pollard, 1981). The businessman, however, tends to view his major responsibilities as being divided into five categories: personnel, finance, marketing, production, and planning. Stated another way, the businessman's major management functions are related to money, to a product, to people, and to a process which, if he is an effective manager, is directed and coordinated by following a plan of action (Quade, 1989).

The term "effectiveness" in a nonprofit organization is concerned with the accessibility, suitability, quality, and the economy with which the services are delivered to the population (Norris, 1984). Simply stated, a hospital's effectiveness is the impact on the people's health by the resources that the hospital controls and spends. It is the ration of health care results to expenditures. But what is meant by "impact" on the people's health? What are the "health care results" that are incorporated in the effectiveness concept (Siendwall \& Tavani, 1991)? The purpose of this study was to examine the Locus of Control orientation of graduate and undergraduate students. More specifically, the researcher was concerned with ascertaining the effect of the college-major variable (Business Administration versus Health Care Administration) and classification (graduate versus undergraduate) of the internal, external, and overall Locus of Control orientations.

\section{STATEMENT OF HYPOTHESES}

The following hypotheses were formulated and tested in this investigation:

HO$_{1}$ : As measured by the Rotter's Locus of Control Scale, there will be no statistically significant difference between the external orientation scores of Business Administration and Health Care Administration students.

$\mathrm{HO}_{2}$ : As measured by the Rotter's Locus of Control Scale, there will be no statistically significant difference between the external orientation scores of graduate and undergraduate students.

$\mathbf{H O}_{3}$ : As measured by the Rotter's Locus of Control Scale, there will be no statistically significant difference between the overall Locus of Control scores of graduate and undergraduate students of Business Administration; and

HO$_{4}$ : As measured by the Rotter's Locus of Control Scale, there will be no statistically significant difference between the overall Locus of Control scores of graduate and undergraduate students of Health Care Administration. 


\section{PRIOR RESEARCH}

In 1997, Aubrey identified social themes occurring in 10-year spans for the guidance and counseling movements. It would perhaps be important to note here that the terms "career counseling", "career development" and "vocational guidance" all have distinct meanings that are time and culture specific. "Vocational guidance" was the original term used in the U.S. and generally used throughout the world at the beginning of the development of the guidance movement. The terms "career counseling" and "career development" came into more common usage in the 1950's through the work of Super (1955) and were institutionalized when the name of the National Vocational Guidance Association (1913-1983) was changed to the National Development Association in 1984.

In the first stage of career development in the U.S. (1890-1919), placement services were offered for an increasingly urban and industrial society. In the second stage (1920-1939), educational guidance through the elementary and secondary schools became the focal point. The third stage (1940-1959) shifted to colleges and universities and the training of counselors. The fourth stage (1960-1979) was a boom for counseling, and the idea of work having meaning in a person's life came to the forefront (organizational career development began during this period). The fifth stage (1980-1989) saw the beginning of the transition from the industrial age to the information age, as well as the growth of both the independent practices of career counseling and outplacement counseling. Finally, the sixth stage (starting in 1990) with its emphasis on technology and changing demographics, has shown an increasing sophistication in the use of technology, the internalization of career counseling, and a focus on the school-to-job transition.

Likewise, in 1999 Muhonen investigated the effects of individual and situational factors on the career development of women. The sample consisted of 399 women managers from both the private and public sectors, and also women from both male- and female-dominated careers. A questionnaire, along with interviews and diaries, was used to collect the data. Multiple regression procedures were then used to analyze the data. Muhonen found that both individual factors (work, Locus of Control, educational level) and structural factors (male hierarchy and support from spouse) were related to the females' managerial advancement. Additionally, the results revealed that both situation- and individual-related factors could also provide some hindrance for female career development.

In his dissertation study, Barren (1999) investigated the effects of existential-phenomenological counseling on Locus of Control, self-efficacy, and aggression on the career development of police officers. The sample consisted of 24 police officers with 12 in the experimental group (group counseling interventions) and 12 in the control group (no counseling interventions). The Self-Efficacy Scale, the Relief in Personal Control, the Aggression Questionnaire, and a Demographic Survey were utilized to collect the data and a multiple analysis of co-variance (MANCOVA) was used to examine the data. Barren found that an external Locus of Control predictor was that of undesirable behaviors.

\section{THEORETICAL VARIABLES THAT AFFECT CAREER DEVELOPMENT}

Lent, Brown, \& Hackett's (1994) model, for example, dealt with the effect of self-efficacy, beliefs, expected outcomes, goal mechanisms, and how these variables interrelate with gender, contextual, experimental, and learning factors. Their variables are built on the status attainment model of Blau \& Duncan (1967). As a result, their model linked family and cognitive variables to social psychological processes, educational choices, and occupational attainment.

\section{Family Variables}

Parents' expectations for their children have received much attention in the literature. In general, most of the findings have suggested that parental expectations are positively correlated with the students' aspirations (Man, 1995). For example, Wilson \& Wilson (1992) reported that maternal expectations for the students might have the greatest impact on the students' aspirations. Smith (1991) claimed that the students' agreement with parental expectations was positively correlated with (and had the greatest effect on) his or her aspirations. Shepard (1992) found that positive change in parental aspirations over a two-year period had a greater effect on the student's 
aspirations than those parental expectations that did not change. Finally, Farrell \& Pollard (1987) found that the positive influence of aspirations or expectations was not limited to parents; that is, expectations by other significant people were positively related to students' aspirations.

\section{Psychological Variables}

The results of various research studies on the relationships between psychological variables and students' educational and vocational aspirations have indicated that, compared to lower aspirations, students with higher aspirations are more likely to have higher self-esteem (Lay \& Wakstein, 1985; Mau, 1995). They also found that the same individuals would likely have higher self-concept and an internal Locus of Control (Mau, 1995). Moreover, these students were likely to place more importance on having a high status job and spent more time thinking about their post high school plans (Shepard, 1992). The self-efficacy construct has proven to be an important individual difference variable in vocational psychology (Bandura, 1986; Betz, Harmon, \& Borgen, 1996). Prior career development research has strongly suggested that at different ages and across diverse populations, situation specific, self-referent expectations substantially influence the vocational development process for both men and women (Career Development Quarterly, 1996).

\section{School Variables}

Variables related to school performance are positively correlated with high school students' educational and occupational aspirations (Farrell \& Pollard, 1987; Harris, 1970). Specific measures of these variables include: grade point average, change in grade point average over two years' reading, and science and mathematics proficiency (Shepard, 1992; Mau, 1995). Other research has indicated that aspects of the school environment, such as teachers' counseling and advisement, positively influence students' aspirations (Marjonbanks, 1985; Wilson \& Wilson, 1992).

\section{Sex And Race Variables}

In 1996, Arce conducted a study of college students from two different cultural and social backgrounds who were undecided about careers as determined by indecision, social support, and self-esteem scores. The results of this study were mixed. Similarly, in a 10-year study, Hauser and Anderson (1991) found no significant difference in the aggregate trends in the aspirations of black and white students. These studies, which found no differences due to race and gender, were consistent with the Kelsey (1983) study that was conducted to examine the relationship between Locus of Control and career decision-making styles among black and white college students. The population of this study consisted of junior and senior students from Georgia. Three instruments were used for data collection: a demographic questionnaire, the Adult NovickiStrickland Internal-External Scale, and the Assessment of Career Decision-Making Styles Scale. Multiple regression and multiple analysis of variance procedures were used to analyze the data. Results of the three pre-tested groups across gender indicated that no significant differences (as measured by six different scales) existed. Furthermore, there were no significant post-test differences among the three treatment conditions. However, a univariate significant difference was found on one dependent measure. Significance was found on problem-solving as it affected "good" career decision-making choices.

\section{Sociological Variables}

The sociological research on career development focused on cultural and social aspects affecting career choice (e.g., class, ethnicity, and culture). Pure sociological perspectives took into account other factors, such as labor demands and technical advances. These studies, which went far beyond examining an individual's control, suggested that the latter factors have a direct impact on industrial career choice (Brown \& Brooks, 1990). In contemporary sociological theory, greater attention has been given to status attainment research (Hotchkiss \& Borow, 1984, 1990). The status attainment theory, as it relates to career decisions and career development, suggests that the social status of a student's parents affects the level of schooling he or she will achieve, which in turn affects his or her level of occupational attainment. 
In other words, within the status attainment model there are obstacles that present certain kinds of indecisiveness (education, occupation, and income) that ultimately affect career decision-making and career development, as well as the career outcome. Based on the status attainment model, career indecisiveness would tend to suggest that students lack significant interpersonal relationships with influential people throughout their adolescent lives. In this particular model, race and gender no longer seem to be strong determinants of one's career goals. Instead, other characteristics, such as societal circumstances and demographics, appear to be significant determinants affecting career decision-making and career goals among college students.

\section{Type Of Design}

An Ex Post Facto research paradigm was utilized in this investigation, whereby major and classification were the independent variables and Locus of Control orientation was the dependent variable. This type of research methodology involved selecting two groups of respondents, who were different on some individual variables, and comparing them on a dependent variable (Gay, 1996). Moreover, the Ex Post Facto design allowed the investigator the opportunity to examine the independent variable, which was manipulated. In so doing, it identified variables worthy of experimental investigation (Gay, 1996). The preceding advantages offered by the causal comparative design provided the most practical methodological framework to study the Locus of Control among Business Administration students and Health Care students.

\section{Population}

The population for this investigation consisted of a total of 140 college seniors and graduate students in Health Care Administration and Business Administration at Texas Woman's University and Texas Southern University, both located in southeastern Texas.

\section{Sampling Procedures}

A simple random sampling procedure was used to select the sample for this study. In other words, each participant in the relevant population had an equal chance of participating in the study. First, the names of each student in the Business Administration and Health Care Administration departments at the target institutions were identified. Once identified, each student was assigned a number from 001 to $\mathrm{N}$, where $\mathrm{N}$ was the total number of students in each discipline at the institutions. The Table of Random Numbers was used to select the sample. Finally, the random sample of 88 Business Administration and 37 Health Care Administration students was drawn from the student roster at the two institutions. According to Fox (1969), when the population of a study is known, a sample size greater than $10 \%$ is considered representative of that population. Inasmuch as there were 210 Business Administration and 75 Health Care Administration students enrolled at the institutions, a sample size of 125 (88 Business majors and 37 Health Care majors) was deemed representative for this study.

\section{Data Collection Procedures}

The investigator mailed a letter and the research proposal application to the deans of the respective departments at the target universities. The research application summarized the theoretical framework of the study and outlined the methodological procedures to be used. The deans were informed that a copy of the results would be made available to them, if they so desired. Finally, an authorization letter was obtained from the deans before proceeding with the study. The procedure for administering the surveys involved a two-step process. First, the researcher notified the deans and asked them to serve as contact persons to assist in the administration of the instrument. Once this amicable relationship was established, the researcher met with the deans and delivered the research package containing a copy of the instrument, a cover letter, and a stamped envelope for return of the completed forms. The researcher asked the deans to return the questionnaires at their earliest convenience. To ensure anonymity of the participants' responses, their names were omitted. Later, all completed surveys were logged and examined for non-responses and errors, and instruments not properly completed were discarded. Once all questionnaires were properly examined and coded, they were analyzed using the Statistical Package of the Social Sciences (SPSS) software. 


\section{INTERNAL ORIENTATION PARTICIPANTS}

\section{Gender}

There were 73 students identified as 'internal' orientation with respect to their Locus of Control, as measured by the Rotter's Locus of Control Scale. Of these, 29 (39.7\%) were male and 44 (60.3\%) were female.

TABLE 1: Frequency Distribution of Internal Orientation Participants by Gender

\begin{tabular}{|c|c|c|}
\hline \hline Gender & N & Percent \\
\hline Male & 29 & 39.7 \\
\hline Female & 44 & 60.3 \\
\hline Total & 73 & 100 \\
\hline
\end{tabular}

\section{Major}

In reference to the internal orientation of the student's major, 38 were enrolled in Business Administration. In comparison, 35 (47.9\%) of them were specializing in Health Care Administration.

TABLE 2: Frequency Distribution of Internal Orientation Participants by Major

\begin{tabular}{ccc}
\hline \hline Major & N & Percent \\
\hline Business Administration & 38 & 52.1 \\
Health Care Administration & 35 & 47.9 \\
Total & 73 & 100.0 \\
\hline
\end{tabular}

\section{Classification}

In the present study, the 73 internal orientation students were classified as either undergraduate or graduate. There were $60(82.2 \%)$ undergraduate and $13(17.8 \%)$ graduate students.

TABLE 3: Frequency Distribution of Internal Orientation Participants by Classification

\begin{tabular}{ccc}
\hline \hline Classification & $\mathbf{N}$ & Percent \\
\hline Undergraduate & 60 & 82.2 \\
Graduate & $\mathrm{j}$ & 17.8 \\
Total & 73 & 100.0 \\
\hline
\end{tabular}

\section{Classification Within Major}

In the present study, 73 internal orientation students were classified as undergraduate and graduate students of Health Care Administration. There were $22(30.2 \%)$ undergraduate and $15(20.5 \%)$ graduate students of Health Care Administration and there were $30(41.1 \%)$ undergraduate and $6(8.2 \%)$ graduate students of Business Administration that participated in the investigation.

TABLE 4: Frequency Distribution of Internal Orientation Participants by Classification Within Major

\begin{tabular}{ccc}
\hline \hline Classification & $\mathbf{N}$ & Percent \\
\hline Undergraduate Health Care & 22 & 30.2 \\
Graduate Health Care & 15 & 20.5 \\
Undergraduate Business Admin. & 30 & 41.1 \\
Graduate Business Admin. & 6 & 8.2 \\
Total & 73 & 100.0 \\
\hline
\end{tabular}




\section{EXTERNAL ORIENTATION PARTICIPANTS}

\section{Gender}

There were 52 students in this empirical study who were identified as having an 'external' orientation based on the results of the Rotter's Locus of Control Scale. Of these, 19 (36.5\%) were male and $33(63.5 \%)$ were female.

TABLE 5: Frequency Distribution of External Orientation Participants by Gender

\begin{tabular}{ccc}
\hline \hline Gender & N & Percent \\
\hline Male & 19 & 36.5 \\
Female & 33 & 63.5 \\
Total & 52 & 100.0 \\
\hline
\end{tabular}

\section{Major}

Regarding the major of external orientation students, 23 (44.2\%) indicated they were majoring in Business Administration. By contrast, 29 (55.8\%) reported they were majoring in Health Care Administration.

TABLE 6: Frequency Distribution of External Orientation Participants by Major

\begin{tabular}{ccc}
\hline \hline Major & N & Percent \\
\hline Business Administration & 23 & 44.2 \\
Health Care Administration & 29 & 55.8 \\
Total & 52 & 100.0 \\
\hline
\end{tabular}

\section{Classification}

Students' classification was either undergraduate or graduate. There were $28(53.8 \%)$ undergraduate and $24(46.2 \%)$ graduate students identified as having external orientations in this study (See Table 12).

TABLE 7: Frequency Distribution of External Orientation Participants by Classification

\begin{tabular}{ccc}
\hline \hline Classification & N & Percent \\
\hline Undergraduate & 28 & 53.8 \\
Graduate & 24 & 46.2 \\
Total & 52 & 100.0 \\
\hline
\end{tabular}

\section{CONCLUSIONS}

Based on the findings of this research, the following conclusions were drawn:

1. Business Administration and Health Care Administration students generally had similar overall Locus of Control orientation scores;

2. In general, it appears that graduate students had higher overall Locus of Control orientation scores than did undergraduate students;

3. Internal Locus of Control orientation scores were similar for Business Administration and Health Care Administration students;

4. Graduate and undergraduate college students generally had similar internal Locus of Control orientation scores: 
5. In general, Business Administration students had higher external Locus of Control scores than their Health Care counterparts; and

6. Students' classification (graduate and undergraduate) had no influence on their external Locus of Control orientation scores.

\section{RECOMMENDATIONS FOR THE FIELD OF COUNSELING EDUCATION} consideration:

The researcher offers counselors and other health professionals the following recommendations for

1. Counselors, especially those who are involved with assisting students in the Business Administration and Health Care fields, should be aware of the Locus of Control orientation of these students. An understanding of how students perceive their environment can help counselors develop strategies to enhance the students' social, personal, and psychological well-being;

2. Counselors and other concerned individuals should be cognizant of the characteristics and traits of internally and externally oriented students. Being able to identify control orientation will allow counselors and other health care professionals to predict the type of counseling intervention that will be most helpful in preparing students to meet their professional goals and careers;

3. Finally, counselors should understand the impact that background and social characteristics have on the Locus of Control behaviors of college students. It is important that counselors gain more awareness of the interplay of these variables the way students see themselves in relation to their environments.

\section{REFERENCES}

1. Health Manpower Report (1975). The Kaiser Foundation Hospitals. Health Administration Press, Ann Arbor, Michigan, p39.

2. John Hopkins University established its School of Hygiene and Public health in 1916; by 1922 Harvard, Yale, Colombia and Michigan had commenced similar programs. The early development of Schools of Public Health is summarized in Higher Education for Public Health. A report of the Milbank Memorial Commission (SHEPS) New York, 1976.

3. Marquette University set up a Hospital Administrated program in 1925 which folded in 1929. Duke University established a certified-awarding program in 1930. Report of the Commission on University Education for administration of Hospitals (Olsen) American Council on Education, Washington, D.C., 1954.

4. Study made by the American Hospital Association, Hospital statistics (1976) edition, 206.

5. University Education for Administration of Hospital (1954). American Council on Education, Washington, D.C.

6. University Education for Administration of Hospitals (1976). Report of the Commission on University Education on Hospital Administration. American Council on Education, Washington, D.C.

7. University education for Administration of Hospitals, Report of the commission on University education in Hospital administrated (Olsen). American Council on education, Washington, D.C., 1954.

8. Aaron H.J., (1991). Serious and Unstable Condition: Financing America's Healthcare, Washington, D.C., Brooklings, Institute.

9. $\quad$ Ackoff, R.L., (1979) Towards a System of Systems Concepts. Management Science. No 11 (July).

10. Anderson, E.A. (1962) Uneasy Equilibrium. New York. M.D. Publication.

11. Austin, C.J. et, al., (1974). Education for Health Administration: A statistical Profile in Education for Health Administration. Eastern Psychological Association Convention, Washington, D.C.

12. Baines d. et.al. (1995). Primary Healthcare and Primary Care: A confusion of philosophies. Nursing Outlook 39: 54-55, March-April.

13. Bandura, Albert (1968) Social Learning and Personality Development. New York, N.Y.: Holt, Rinehart and Winston. 282, 294.

14. Beer,S., (1986) Decision and Control, New York, John Wiley and Sons. 
15. Berki, S.E., (1983) Health Care Policy :Lessons from the Part and Issues of the Future. Annals of the Academy of Political and Social Science. 468 (July).

16. Blau G (1993). Testing of Control to Different Performances Dimensions. Journal of Occupational and Organizational Psychology, 66, 124-138.

17. Blau, P.M., and Scott, R.W., (1962)Formal Organizations, Chandler Publishing Co., San Franciso, , p. 6063.

18. Braustien, J. (1991). National Healthcare: Necessary but sufficient. Nursing Outlook 39; 54-55, MarchApril.

19. Brooks, E.R. (1993) Does Free Care Improve Adult Health. New England Journal of Medicine. Vol. 309, No. 23.

20. Brown, D., Fulkerson, K.E., Furr, S., and Ware, W.B. (1984) Locus of Control, Sex role orientation, and self-concept on black and white Third and Sixth grade male and female leaders in rural communities. Development Psychology, 20,717-721.

21. Bucher, R., and Stelling, J., (1991). Characteristic of Professional Organizations. Journal of Health and Social Behavior, No.10. pp. 13-15.

22. Burnes, K., Brown, W.A, and Keting, G.W., (1967). Dimensions of Connecticut and Wesleyan University. Journal of Consulting Psychology. Vol. 31. No 6, pp. 609-13.

23. Caplan, R.D., Cross, S., French, J.R. Jr., et.al (1975) Job Demand and Workers Health. Washington, D.C., U.S. Department of Health and Human Services.

24. Cardi, M., (1962). An Examination of Internal versus external Control in Relation to Academic Features, Ohio State University.

25. Chollet, D.J., (1984) Employer-Provided Health Benefits: Coverage, Provisions and Policy Issues. Washington, D.C., Employees Benefits research Institute.

26. Cohen, Richard (1993). Ready, Aim, Reform: National Journal, Vol. 25, No. 44.

27. Cohen, Victor (1990) . Rationing Medical Care- The Case of Companies Managed Care. Washington Post National Weekly Edition. August 13-19.

28. Costa, P.T Jr., and McCrae, R.R (1989) The Neo-PI/Neo-FFI Maniacal Supplement, Odessa, FL. Psychological Assessment resources.

29. Crittenden, Robert (1993) Managed Competition and Premium Caps in Washington State. Health Affairs, No. 12.

30. Crozier, D.A., (1982) State Rate Setting: A Status Report. Human Affairs, No.2.

31. Davis, K. (1991) Expanding Medicare and Employer Plan to Achieve Universal Health Insurance. Journal of the American Medical Association. 265. No. 19.

32. Davis, K., Anderson, D.R. and Steinberg, E.P. (1995) Health Cost Containment. Journal of Health Politics, Policy and Law, 39, Vol.2.

33. Demkovich, L.E., ( 1979) Adding Competition to the Health Industry, National Journal. October p176180.

34. Dorfman, R. (1980) Operations Research. American Economic Review. Vol. 100.

35. $\quad$ Dreifus C., (1995). Present Shock, The New York Times 46-50, June 11.

36. Duranberger, D.F. (1982) The Politics of Health. Competition in the Market place: Health Care in the 1980 's. New York, Spectrum Publications.

37. Elmwood, P.M. (1993) Health Maintenance Strategy. New York Times. Vol. 10 (March).

38. Emerson, H., (1969) Local Health Units of the Nation: A Report for the American Public Health Association. Committee on Administration.

39. Esposito, Alfonso (1982) State Legislated Hospital Cost Containment Programs. Health Care Financing Review. Vol. 4, No.2.

40. Eysenck, M.W., and Morley, S. (1994) Neuroticism Extraversion, Work Locus of Control, and Work Style. Journal of Indian Academy of Applied Psychology, 20, 111-115.

41. Falkson, J.L. (1990). HMOs and the Politics of Health Service Reform, Chicago: American Hospital Association.

42. Feng, L,I. (1997) Age Differences in Locus of Control and Self-Monitoring in China. Psychological Reports. 81.

43. Flagle C.D. (1982). Operation Research in Health Science. Operation Research, January edition. 
44. Flexner, Abraham (1915). Professional medical education in the United States. The Carnegie Foundation for Advancement of Teaching.

45. French, H.E., and Ginsburg, P.B. (1988) Competition among Health insurers Revisited. Journal of Health Polities, Policy and Law. Vol. 13, No.6.

46. Fox, D.M., (1986). Health Politics, The British and American Experiences. 1911-1965. Princeton: Princeton University Press.

47. Gardner, D.C., (1981): Career maturity and locus of control: Important variables in career training. College Student Journal. Fall.

48. Glanty K., et al (1990). Health behavior and health Education: Theory, Research and Practice, San Francisco: Jossey Bass.

49. George, C.S., (1988). The History of Management Though. Englewood Cliffs, NJ: Prentice-Hall.

50. Gordan, P.S., (1988). Top Management Triangle in Voluntary Hospital. Journal of Academy of Mangement. Reprint (1988).

51. Gore, P.M., and Rotter, J.B. (1969). A Personality Correlate of Social Action. Journal of Personaity. No. 31.58-64.

52. Gottfreedom, L.S., and Becker, H.J., (1981): A challenge to vocational psychology, how important are aspirations in determining male career development? Journal of Vocational Education 18, 121-137.

53. $\quad$ Grace, P.B., (1992) Managed Care: Inquiry Vol. 30 (Spring).

54. Graig, L.A., (1993). Health of Nations: An International Perspective on U.S. health Care Reform. Washington, D.C.: CQ Press.

55. Gruber, W.H. and Niles, J.S., (1971) Problems in the Utilization of Management. Science/Operations Research. Vol. 2. No. 1.

56. Gurin, P.M., Gurin, G., and Lao, R., et.al; (1969). Internal-External Control in the Motivational Dynamics of Negro Youth. Journal of Social Issues. No. 25. 29-53.

57. Haire, M., (1987) Coming of Age of Social Sciences. Industrial Management Review, Spring.

58. Havighurst, C.C., (1990) Health Maintenance Organization and the Market for Health Services. Health Financing Review. Vol. 34, No.2.

59. Holland, J.L., (1985) Making vocational choices: a theory of careers. Englewood, Co. Prentice-Hall.

60. Horvath, W.J., (1964) British Experience with Operation research in the Healthcare. Journal of Chronic Disease. Vol.17.

61. Horvath, W.J., (1982) The System Approach to the National Health Problems. Management Science, Vol. 15, No.12.

62. Jones, S.B., (1990) Multiple Choice Health Insurance: The Lessons and Challenges to Private Insures. Inquiry. Vol. 25. No. 2.

63. Kelly L.S. (1991). Another look at the future of health care. Nursing Outlook 39: 150-151. July-August

64. Kellogg Foundation M (1994). How people view their providers. Report of Survey, June.

65. Kleiber, D., Veldman, D.J., and Meneker, S.L., (1974). The Multidimensionality of Locus of Control. Paper presented to Eastern Psychological Association Convention, Washington, D. C.

66. Latham, Bryan (1983) Health Care Cost: There are Solutions. New York. American Management Association.

67. Lave, Judith, R. (1984) Hospital reimbursement under Medicare. Milbank Memorial Fund. Quarterly / Health and Society. Vol. 62, No. 2.

68. Lefcourt, H. M., (1976). Locus of Control Current Trends in Theory and Research, Lawrence Eribourn Associates, Publisher Hillsdale, New Jersey.

69. Levenson, Hannah., (1973) Multidimensional Locus of control in Psychiatric Patients, Journal of Consulting and Clinical Psychology, 41: 397-404.

70. Levenson, Hannah., (1974). Perceived Parental Antecedents of Internal Powerful Others and Chance, Locus of Control Orientation, Development Psychology 9: 268-274.

71. Levenson, Hannah., (1974). Activism and Powerful Others: distinctions within the concept of InternalExternal Control. Journal of Personality Assessment, 38,377-383.

72. Levenson, Hannah., (1973). Multidimensional Locus of Control in Psychiatric Patients, Journal of Consulting and Clinical Psychology, 41: 397-404.

73. Leyerle, Betty (1994) The Private Regulation of American Healthcare Amok, NY. M.E. Sharp. 
74. Luft, Harold (1978) How does Health Maintenance organization Achieve their Savings/ Rhectoric and Evidence. New England Journal of Medicine 298. Vol. 24.

75. May, Joel J., (1935) Health Planning: It's Past and Potential: Chicago: University of Chicago, Center for Health Administration.

76. Mills, A.B., and Mills, P., (1997) The Need for More Hospitals. The Modern Hospital. Vol. 44

77. McMillian, Alma (1994) Managed Care and its Enrollment: The New Trends. Health Care Financing Review. Vol. 20. No.6.

78. Moran, D. W., (1987) HMOs, Competition and the Politics of the Minimum Benefit. Inquiry, Vol. 50.

79. Morrison. K.A., (1997) Personality Correlates of the Five Factors Model for a Sample of Business Owners/Managers: Associations with Scores on Self-Monitoring. Type A Behavior and the Locus of Control and the Subjective Well-Being. Psychological Report. Vol. 88. Pp. 225-272.

80. Nunnalix, J.C. (1978) Psychometric Theory ( $2^{\text {nd }}$ Ed). New York : Mc Graw-Hill.

81. Nunnalix, J.C., and Bernstein, I.H., (1994) Psychometric Theory ( $3^{\text {rd }}$ Ed). New York: Mc Graw-Hill.

82. Orpen, C. (1992) The Work Locus of Control Scale as a Predictor of employee attitudes and behavior: a validity study. Psychology, A Journal of Human Behavior, 29, 34, 37.

83. Phares, E.J. (1976) Locus of Control in Personality. Morristown, N.J. General Learning Press.

84. Rosen, George., (1958) A History of Public Health. New York, MD Publications

85. Rotter, J.B., (1966). Generalized Expectancies for Internal versus External Control of Reinforcement, Psychology Monographs (80) 1.

86. Rotter, J. B., (1971). External-Internal Control, Psychology Today, 37-58 (June).

87. Scheir, N.R., (1991) Health Care Marketing, not for Large Institutions, Only. Hosptial Topics, May/June, 16.

88. Seeman, M., (1963) Alienation and Social Learning in Reinforcement, American Journal of Sociology, Vol. 69, 270-84.

89. Siendwall D. Tavani C. (1991). The role of public health in providing primary care for the medically underserved. Public Health Report 106:2-4, January - February.

90. Spector, P.E. (1988). Development of the work Locus of Control Scale. Journal of Occupational Psychology, 61, 335-340.

91. Starck, P.L. (1991). Health under siege. Challenge for change. Nursing Health Care 12: 26-31, January.

92. Stanfield P. (1991). Introduction to the Health Profession, $2^{\text {nd }}$ Edition. Boston: Janes \& Barlett.

93. Stebbins, E., (1976) History of Health Planning. Modern Hospital. Vol. 40.

94. Stratton, W.E., and Flynn, W.R., (1978). The Need for Management development in Health Care Institutions, Hospital Topics September/October, 26.

95. Struwassner, Ira., et.al. (1992). Traditional Coverage, HMOs and PPOs. Inquiry. Vol. 32.

96. Sullivan, Sean., (1984). Managing Health Care Costs. Washington, D.C., American Enterprise for Public Policy Research.

97. Super, D.E. (1957). The Psychology of Careers. New York: Harper and Row Books.

98. Super, D.E. (1990) : A Lifespan, life space approach to career development ( ${ }^{\text {nd }}$ Edition), San Franciso, CA. Jossy-Bass Pp. 197-261.

99. Super, D. E. Starishersky, R, Malin, N., and Jordaan, J.P. (1963) Career development and self concept theory. New York: College Entrance Examination Board.

100. Terris, Milton., (1990) A Wonderful System that does not Work. The Progressive, (October) 14-16.

101. Viguers, R.T (1978). The Polities of Power in a Hospital, Modern Hospital 96: 89-94.

102. Wallaston, K., and Wallaston, B., (1982). Who is Responsible for your Health?

103. G. Sanders and G. Suls (Eds). The Construct of Health Locus of Control in Social Psychology of Health and Illness (pp. 65-95), Hillside NJ: Lawrence Erlbaum.

104. Wilensky, H. L., (1962). Dynamics of Professionalism - The Case of Hospital Administration, Hospital Administration No. 7 6-24. 
NOTES 